\title{
Timing factors as prognostic variables in patients with head and neck squamous cell carcinoma treated with adjuvant radiotherapy: a literature review
}

1. Programa de Pós-Graduação, Departamento de Oncologia, Instituto do Câncer do Estado de São Paulo (Icesp), Universidade de São Paulo, São Paulo, SP, Brasil. 2. Universidade Federal do Paraná - Hospital de Clínicas, Curitiba, PR, Brasil 3. Departamento de Radiologia e Oncologia, Divisão de Radiação, Ocológica, Instituto do Câncer do Estado de São Paulo (Icesp), Faculdade de Medicina da Universidade de São Paulo, São Paulo, SP, Brasil

http://dx.doi.org/10.1590/1806-9282.66.3.380

\begin{abstract}
SUMMARY
INTRODUCTION: Radiotherapy (RT) plays an important role in the treatment of patients with head and neck neoplasia, and is frequently used as postoperative adjuvant therapy. This study aimed to review the literature about timing factors that may influence the clinical outcomes of patients with advanced head and neck neoplasia treated with adjuvant RT.

RESULTS: Timing factors such as total treatment time, length of adjuvant RT, and the absence of interruptions during RT may influence the clinical outcome of these patients.

CONCLUSIONS: In the same way that certain tumor factors can affect the prognosis of patients with squamous cell carcinoma of the head and neck, some therapeutic timing factors are also prognostic factors and therefore, must be carefully orchestrated in order to avoid loss at therapeutic outcomes for these patients.
\end{abstract}

KEYWORDS: Head and neck neoplasms. Radiotherapy. Carcinoma, squamous cell. Prognosis. Review literature as topic.

\section{INTRODUCTION}

Tumors originated in the head and neck region represent $4 \%$ of all neoplasias worldwide, with 380,000 deaths and 560,000 new cases estimated yearly ${ }^{1}$. In about two-thirds of the cases, the diagnosis of these tumors is performed in advanced clinical stages, which usually determines a higher number of cases with guarded prognosis, in addition to the need of multidisciplinary treatment including surgeons, clinical oncologists, and radiation oncologists, as well as nurses, dentists, nutritionists, psychologists, speech therapists, and physical therapists ${ }^{2}$.

Radiotherapy (RT) is often used in the treatment of patients with advanced the head and neck cancer as a postoperative adjuvant therapy with the objective of reducing the likelihood of local recurrence due to its ability to eradicate the remaining neoplastic cells that could evolve to a locoregional recurrence. Gilbert Fletcher introduced, in the 1950s, the concept of 
postoperative RT in squamous cell carcinoma of the head and neck after observing high rates of recurrence with surgical treatment alone ${ }^{3}$. Since then, the risk reduction of locoregional failure with the use of adjuvant RT has been repeatedly documented, confirming its ability to improve the rates of local control, progression-free survival, and overall survival ${ }^{4}$.

In 2004, two independent randomized clinical studies, one conducted by the European Organization for Research and Treatment of Cancer (EORTC 22931) and another led by the Radiation Therapy Oncology Group (RTOG 9501) ${ }^{6}$, published data with a high level of evidence justifying the use of concomitant adjuvant radio-chemotherapy due to the benefit of local control and progression-free survival in patients with a high risk of recurrence.

Although surgical resection followed by adjuvant RT, with or without chemotherapy, is the standard treatment for a good number of locally advanced tumors, it still presents unsatisfactory results, with rates of $30 \%$ of locoregional failure, $25 \%$ of distant metastases, and survival in five years around 40\%$50 \%$. In addition to the clinical factors related to the tumor, some aspects related to the treatment, such as the total treatment time (TTT), the duration of RT, and the interval between surgery and the beginning of RT, also seem to have a prognostic impact on the clinical outcome of these patients since a delay to start the treatment seems to affect mainly patients with tumors of accelerated cell multiplication, such as squamous cell carcinoma of the head and neck. A delay to start the treatment seems to affect mainly patients with tumors of accelerated cell multiplication, such as squamous cell carcinoma of the head and neck, because their doubling time and speed of growth are directly related to the local control of the tumor $^{8}$. In order to describe temporal factors that may impact the clinical outcomes of patients with advanced neoplasia of the head and neck treated with adjuvant RT, we propose this integrative literature review.

\section{RADIOBIOLOGY AND TUMOR BIOLOGY OF HEAD AND NECK NEOPLASIAS}

Adjuvant RT for the treatment of patients with head and neck cancer is usually administered daily, five times per week, for an average of five to seven weeks.

Cell death as a result of RT occurs by mechanisms at molecular levels and may happen through apoptosis or post-mitotic cell death (the predominant mechanism of radio-induced cell death). While apoptosis manifests rapidly after cell aggression, cell death after mitosis depends on the tumor tissue turnover time. In it, the chromosome damage caused by radiation only manifests when the cell tries, without success, to reproduce itself. Thus, there is a latent lag phase from the radio-induced chromosome damage to the manifestation of post-mitosis death. Furthermore, the depletion of tumor cells as a result of RT is a stimulus for accelerated clonogenic multiplication of the

remaining tumor cells, with increased number of cells to be eradicated, defining a phenomenon called accelerated repopulation, as illustrated in Figure 1. Thus, tumor cell repopulation increases with the duration of the radiotherapy treatment, with a higher rate after the first two weeks of treatment; being critical a therapeutic course interruption, especially at this stage. In this regard, Malaise and Tubiana ${ }^{9}$ have demonstrated that the repopulation of fibrosarcoma transplanted into mice increased with the duration of treatment and was faster after a single fraction of RT than in non-irradiated tumors.

The radiobiological concepts that describe the rapid tumor repopulation after the start of RT give reason to expect the same with residual cells after surgical intervention. The surgical site is a favorable environment for cell proliferation since it is rich in growth factors that promote tumor cells, angiogenesis, and micrometastases, and the postoperative recovery period could be an opportunity for the tumor cells to become radio-resistant since its resistance increases with the number of cell multiplications ${ }^{10}$. What happens, however, is that different treatment techniques (radiotherapy or surgery) present different intervals for the onset of accelerated cell repopulation. According to the Gompertz model of volume-dependent

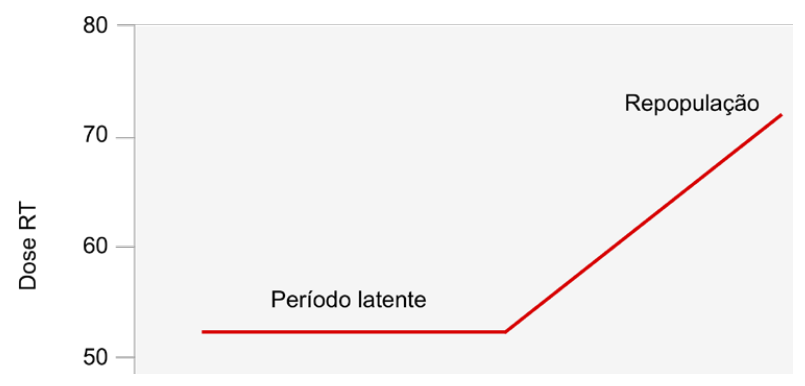

FIGURE 1. INITIAL LATENT STAGE AFTER RADIOINDUCED CELL DAMAGE FOLLOWED BY AN ACCELERATED REPOPULATION PEAK FROM THE MANIFESTATION OF CELL DEATH AND DEPLETION CAUSED BY RT 
tumor growth and cell repopulation, regeneration by means of effective growth of neoplastic cells after a surgical treatment is substantially lower $\left(10^{6}-10^{9}\right.$ residual cells in the surgical site) than the growth tumor cells during RT (1 to $10^{6}$ cells) ${ }^{11}$. Extended RT time may have an impact on the likelihood of tumor control, with a possible decrease of $1 \%$ to $2 \%$ for each additional day of treatment, while a extended interval between surgery and the beginning of RT has an impact of approximately $0.17 \% /$ day $^{12}$. Thus, an extended interval between the surgical resection and the beginning of RT seems to be not as deleterious as extended radiotherapy treatment.

\section{TREATMENT DURATION}

Evidences indicates that the duration of postoperative RT, the absence of interruptions during radiotherapy, and the total treatment time (TTT) are determining factors for the final therapeutic results ${ }^{13}$. Withers et al. ${ }^{14}$ have analyzed clinical information grouped from different institutions in order to identify the total RT dose needed to control $50 \%$ of the tumor cells in squamous cell carcinoma of the head and neck. This concept, known as Tumor Control Dose (TCD50) showed a marked increase in treatments that lasted more than four weeks, with need to increase the RT dose for each additional day of treatment, and the concept of accelerated repopulation justifing such a finding. By the same reasoning, when there are long intervals between fractions and a given dose is delivered in a longer period of time, the effectiveness of RT can be limited or compromised, with lower rates of tumor control and an increased likelihood of accelerated tumor growth of approximately 1.0\%-1.5\%

for each additional day of radiotherapy treatment ${ }^{15}$.
Suwinski et al. ${ }^{12}$ found a decrease of $10 \%-30 \%$ of

the locoregional control rate in five years when the treatment lasted for more than 10 days beyond the initially planned. It is estimated that the dose required to override accelerated tumor repopulation per additional day of treatment time is around 0.5 Gy/day-1.0 Gy/day, which may be administered as a second daily fraction, respecting the minimum interval of six hours between the fractions, without the extra dose generating even more additional days of treatment ${ }^{14}$.

Thus, the treatment duration can be used as a the quality of care criteria. The recommendation, according to the treatment protocol used worldwide, the National Comprehensive Cancer Network (NCCN), regarding the time of treatment for patients with head and neck tumors, is that the interval between the surgical resection and the beginning of adjuvant RT should be preferably less than six weeks ${ }^{16}$. However, despite the NCCN recommendation, among the variables that compose the timeline of the adjuvant treatment (duration of RT, the interval between the surgery and the beginning of RT, or total time of treatment from the surgery to the conclusion of RT), one whose oncologic results are still unclear, with a lack of consensus in published studies, is the variation of time between the surgery and the beginning of adjuvant $\mathrm{RT}^{17}$.

After analyzing the studies related to the subject published in the literature up to now, we found great heterogeneity of results, starting with the threshold of time established as safe between the surgery and the beginning of RT. The RTOG 95016 study established in its protocol that adjuvant RT should be initiated within eight weeks of the surgery, but other studies suggest intervals of six weeks at most, while others

\begin{tabular}{|c|c|c|c|c|c|c|}
\hline Author & Year & Design & Cut-of & $\mathrm{N}$ & OS & LRC \\
\hline Schiff et al. ${ }^{19}$ & 1990 & Retrospective & $\begin{array}{l}\text { 0-6 weeks. vs. } \\
>6 \text { weeks. }\end{array}$ & 111 & NM & $\begin{array}{l}5 \text { years } \\
88 \% \text { vs. } 73 \% \\
(p=0.11)\end{array}$ \\
\hline Ang et al. ${ }^{13}$ & 2001 & $\begin{array}{l}\text { Analysis } \\
\text { Retrospective }\end{array}$ & $\begin{array}{l}\text { 0-31 days vs. } \\
\text { >31 days }\end{array}$ & 151 & $\begin{array}{l}5 \text { years } \\
47 \% \text { vs. } 20 \% \\
(p=0.01)\end{array}$ & $\begin{array}{l}5 \text { years } \\
72 \% \text { vs. } 48 \% \\
(p=0.05)\end{array}$ \\
\hline $\begin{array}{l}\text { Langendijk et } \\
\text { al. } .^{\mathbf{2 0}}\end{array}$ & 2003 & Retrospective & $\begin{array}{l}\text { 0-6 weeks. vs. } \\
6-8 \text { weeks. vs. } \\
>8 \text { weeks. }\end{array}$ & 217 & $\begin{array}{l}3 \text { years } \\
79 \% \text { vs. } 73 \% \text { vs. } 73 \% \\
\text { p NS }\end{array}$ & $\begin{array}{l}3 \text { years } \\
57 \% \text { vs. } 57 \% \text { vs. } 60 \% \\
\text { p NS }\end{array}$ \\
\hline Huang et al. ${ }^{8}$ & 2003 & $\begin{array}{l}\text { Systematic } \\
\text { review }\end{array}$ & $\begin{array}{l}\text { 0-6 weeks. vs. } \\
>6 \text { weeks. }\end{array}$ & 851 & $\begin{array}{l}5 \text { years } \\
61 \% \text { vs. } 39 \% \\
(p=0.046)\end{array}$ & $\begin{array}{l}\text { OR } 2.89 \\
(95 \% \text { IC } 1.60-5.21) \\
\text { for an interval of }>6\end{array}$ \\
\hline Graboyes et al. ${ }^{17}$ & 2017 & Retrospective & $\begin{array}{l}\text { 0-6 weeks. } \\
\text { vs. } \\
>6 \text { weeks. }\end{array}$ & 41,291 & $\begin{array}{l}5 \text { years } \\
69.4 \% \text { vs. } 64.3 \% \\
(p<0.001)\end{array}$ & NM \\
\hline
\end{tabular}

$\mathrm{LRC}=$ locoregional control; $\mathrm{N}=$ number of patients analyzed; $\mathrm{NM}=$ not mentioned; $\mathrm{OS}=$ overall survival; $\mathrm{NS}=$ not significative; $\mathrm{OR}=$ odds ratio 
suggest seven weeks ${ }^{18,19}$. Regarding the oncological outcomes of locoregional control or survival, previous studies have also shown heterogeneous results, with some reporting influence in local control and survival ${ }^{13.17}$, and others without the same finding ${ }^{19,20}$. This diversity demonstrates clearly that there is no consensus in determining the appropriate threshold of time until the beginning of postoperative RT, as seen in the table 1.

However, the TTT, defined as the period starting from the date of the surgery to the last day of RT, appears in published studies as a prognostic factor, with the more negative effects on the therapeutic outcome, the more extensive its duration. Parsons et al..$^{21}$ have evaluated the influence of intervals that make up the treatment of patients with tumors of the oral cavity who underwent surgical resection followed by adjuvant RT, detecting better rates of locoregional control when the total treatment did not exceed 100 days $(14 \%$ versus $60 \%, p=0.04$ ). Similarly, Rosenthal et al. ${ }^{22}$ assessed the importance of the time variables that comprise the total treatment duration of patients with head and neck cancer submitted to surgery followed by adjuvant RT, detecting better rates of locoregional control and overall survival in patients who completed the TTT in 100 days.

For this reason, accelerated fractionation, reducing the TTT and decreasing the chance of tumor cell repopulation, is capable of producing better oncologic results when compared to usual radiotherapy fractionation, as documented by several authors ${ }^{23.24}$. A collaborative

Study between the UTMDACC, H Lee Moffitt Cancer Center, and Mayo Clinic randomized patients to receive $63 \mathrm{~Gy}$ in 35 fractions of $1.8 \mathrm{~Gy}$ administered for seven versus five weeks (five weekly fractions for three weeks and then two fractions daily for two weeks) with better rates of locoregional control and survival in the group of accelerated fractionation ${ }^{13}$. The study also showed that the prolonged interval between surgery and RT had a significant impact on the rates of locoregional control and survival of patients who received RT with conventional fractionation, but did not affect the patients who received RT with accelerated fractionation, demonstrating that the total duration of the combined treatment can significantly affect the rates of local control and survival. Thus, the authors recommendation was to aime the TTT as short as possible. Awwad et al. ${ }^{25}$ randomized patients to receive 60 Gy in 30 fractions over 20 days versus $46.2 \mathrm{~Gy}$ in 33 fractions over 12 days in a postoperative scenario and noticed that the accelerated regime had higher rates of locoregional control; with the total treatment duration being the impacting factor for that outcome. They found no influence of the time between surgery and RT on the locoregional recurrence rates for both groups, and the best results were obtained when the total treatment time was less than or equal to 10 weeks $(p=0.005)$.

A prolonged TTT can even override a possible benefit from the escalation of treatment dose, as demonstrated by a study conducted atUniversity of Texas, MD Anderson Cancer Center ${ }^{26}$. They presented the results of 20 years of follow-up of a prospective randomized study after randomizing 246 patients to receive a dose of $57.6 \mathrm{~Gy} / 32$ fractions versus $63 \mathrm{~Gy} / 35$ fractions for volumes considered as intermediate risk, and $63 \mathrm{~Gy} / 35$ fractions versus $68.4 \mathrm{~Gy} / 38$ fractions for high-risk volumes. The authors found no significant difference in the rates of locoregional control and overall survival between the different levels of dose, both intermediate and high-risk groups. However, they noted influence of the total duration of the treatment on the results, with prolonged treatment responsible for lower rates of tumor control, cancer specific survival, and overall survival. The authors speculated that the dose escalation was not successful due to cell regeneration during the extended time for greater delivery of the dose, with tumor repopulation nullifying any advantage gained by the increase of dose.

\section{CONCLUSION}

In the same way that certain tumor factors may affect the prognosis of patients with squamous cell carcinoma of the head and neck, some therapeutic factors, such as the total time of treatment, the duration of RT, and possible interruption of radiotherapy are also capable of impacting therapeutic results and, therefore, must be rigorously orchestrated in order to avoid overlapping losses for these patients.

The results found in this review can assist in the organization and dynamics of treatment centers, aiming to improve medical assistance to patients with head and neck cancer submitted to surgery and adjuvant RT in order to ensure that some treatment factors do not negatively influence the oncological outcomes of patients.

\section{Contribution of the authors}

Rejane Franco - Literature review and data compilation. Gustavo Nader Marta - Literature review, data compilation, and article revision. 


\section{RESUMO}

INTRODUÇÃO: A radioterapia (RT) tem importante papel no tratamento dos pacientes com neoplasia de cabeça e pescoço, sendo frequentemente utilizada como terapia adjuvante a fim de diminuir a probabilidade de recorrência local. O presente estudo tem o objetivo de realizar uma revisão da literatura para avaliar os fatores terapêuticos temporais que possam ter influência sobre os desfechos clínicos dos pacientes com neoplasia avançada de cabeça e pescoço tratados com RT adjuvante.

RESULTADOS: As variáveis terapêuticas, como o tempo total do tratamento, a duração da RT e a ausência de interrupções durante o tratamento radioterápico são capazes de impactar o resultado clínico dos pacientes.

CONCLUSÕES: Da mesma forma que determinados fatores tumorais podem afetar o prognóstico de pacientes com carcinoma de células escamosas de cabeça e pescoço, alguns fatores terapêuticos temporais também constituem fatores prognósticos e, portanto, devem ser rigorosamente orquestrados a fim de se evitarem prejuízos sobrepostos para esses pacientes.

PALAVRas-CHAVE: Neoplasias de cabeça e pescoço. Radioterapia. Carcinoma de células escamosas. Prognóstico. Literatura de revisão como assunto.

\section{REFERENCES}

1. Global Burden of Disease Cancer Collaboration, Fitzmaurice C, Allen C, Barber RM, Barregard L, Bhutta ZA, Brenner H, et al. Global, regional, and national cancer incidence, mortality, years of life lost, years lived with disability, and disability-adjusted life-years for 32 cancer groups, 1990 to 2015: a systematic analysis for the global burden of disease study. IAMA Oncol. 2017;3(4):524-48.

2. Garavello W, Ciardo A, Spreafico R, Gaini RM. Risk factors for distant metastases in head and neck squamous cell carcinoma. Arch Otolaryngol Head Neck Surg. 2006;132(7):762-6.

3. Maccomb WS, Fletcher GH. Planned combination of surgery and radiation in treatment of advanced primary head and neck cancers. Am | Roentgeno Radium Ther Nucl Med. 1957;77(3):397-414.

4. Lundahl RE, Foote RL, Bonner |A, Suman V|, Lewis JE, Kasperbauer |L, et al. Combined neck dissection and postoperative radiation therapy in the management of the high-risk neck: a matched-pair analysis. Int J Radiat Oncol Biol Phys. 1998;40(3):529-34.

5. Bernier J, Domenge C, Ozsahin M, Matuszewska K, Lefèbvre JL, Greiner $\mathrm{RH}$, et al; European Organization for Research and Treatment of Cancer Trial 22931. Postoperative irradiation with or without concomitant chemotherapy for locally advanced head and neck cancer. N Engl I Med. 2004;350(19):1945-52.

6. Cooper JS, Pajak TF, Forastiere AA, Jacobs J, Campbell BH, Saxman SB, et al; Radiation Therapy Oncology Group 9501/Intergroup. Postoperative concurrent radiotherapy and chemotherapy for high-risk squamous-cell carcinoma of the head and neck. N Engl J Med. 2004;350(19):1937-44.

7. Pignon JP, Bourhis J, Domenge $C$, Designé L. Chemotherapy added to locoregional treatment for head and neck squamous-cell carcinoma: three meta-analyses of updated individual data. MACH-NC Collaborative Group. Meta-analysis of chemotherapy on head and neck cancer. Lancet. 2000;355(9208):949-55.

8. Huang J, Barbera L, Brouwers M, Browman G, Mackillop WJ. Does delay in starting treatment affect the outcomes of radiotherapy? A systematic review. J Clin Oncol. 2003;21(3):555-63.

9. Malaise E, Tubiana M. Growth of the cells of an experimental irradiated fibrosarcoma in the C3H mouse. C R Acad Hebd Seances Acad Sci Ser D. 1966;263(3):292-5

10. DeVita VT Jr. The James Ewing lecture. The relationship between tumor mass and resistance to chemotherapy. Implications for surgical adjuvant treatment of cancer. Cancer. 1983;51(7):1209-20.

11. Stephens TC, Steel GG. Regeneration of tumors after cytotoxic treatment. In: Meyn E, Withers HR, eds. Radiation biology in cancer research. New York: Raven Press; 1980. p.385-95.

12. Suwinski R, Sowa A, Rutkowski T, Wydmanski J, Tarnawski R, Maciejewski B. Time factor in postoperative radiotherapy: a multivariate locoregional control analysis in 868 patients. Int J Radiat Oncol Biol Phys. 2003;56(2):399-412.

13. Ang KK, Trotti A, Brown BW, Garden AS, Foote RL, Morrison WH, et al: Randomized trial addressing risk features and time factors of surgery plus radiotherapy in advanced head-and-neck cancer. Int | Radiat Oncol Biol Phys. 2001;51(3):571-8.
14. Withers HR, Taylor JM, Maciejewski B. The hazard of accelerated tumor clonogen repopulation during radiotherapy. Acta Oncol. 1988;27(2):131-46.

15. Withers HR, Peters LJ, Taylor JM, Owen JB, Morrison WH, Schultheiss $\mathrm{TE}$, et al. Local control of carcinoma of the tonsil by radiation therapy: an analysis of patterns of fractionation in nine institutions. Int J Radiat Oncol Biol Phys. 1995;33(3):549-62.

16. National Comprehensive Cancer Network. NCCN Clinical Practice Guidelines in Oncology (NCCN Guidelines): head and neck cancers. Fort. Washington: National Comprehensive Cancer Network; 2017.

17. Graboyes EM, Garrett-Mayer E, Sharma AK, Lentsch El, Day TA. Adherence to National Comprehensive Cancer Network guidelines for time to initiation of postoperative radiation therapy for patients with head and neck cancer. Cancer. 2017;123(14):2651-60.

18. Vikram B. Importance of the time interval between surgery and postoperative radiation therapy in the combined management of head \& neck cancer. Int J Radiat Oncol Biol Phys. 1979;5(10):1837-40.

19. Schiff PB, Harrison LB, Strong EW, Fass DE, Shah JP, Spiro R, et al. Impact of the time interval between surgery and postoperative radiation therapy on locoregional control in advanced head and neck cancer. J Surg Oncol. 1990;43(4):203-8.

20. Langendijk JA, Jong MA, Leemans CR, Bree R, Smeele LE, Doornaert $P$, et al. Postoperative radiotherapy in squamous cell carcinoma of the oral cavity: the importance of the overall treatment time. Int | Radiat Oncol Biol Phys. 2003;57(3):693-700.

21. Parsons JT, Mendenhall WM, Cassisi NJ, Isaacs JH Jr, Million RR. Hyperfractionation for head and neck cancer. Int J Radiat Oncol Biol Phys. 1988;14(4):649-58.

22. Rosenthal DI, Liu L, Lee JH, Vapiwala N, Chalian AA, Weinstein GS, et al. Importance of the treatment package time in surgery and postoperative radiation therapy for squamous carcinoma of the head and neck. Head Neck. 2002;24(2):115-26.

23. Overgaard I, Hansen HS, Specht L, Overgaard M, Grau C, Andersen E, et al. The DAHANCA 6 \& 7 trial: a randomized multicenter study of 5 versus 6 fractions per week of conventional radiotherapy of squamous cell carcinoma of the head and neck. Radiother Oncol. 2000;56(suppl):S4.

24. Hliniak A, Gwiazdowska B, Szutkowski Z, Kraszewska E, Kukolowicz P, Jarzabski $A$, et al. Radiotherapy of the laryngeal cancer: the estimation of the therapeutic gain and the enhancement of toxicity by the one-week shortening of the treatment time-results of the randomized phase III multicenter trial. Radiother Oncol. 2000;56(suppl):S5.

25. Awwad HK, Lotayef M, Shouman T, Begg AC, Wilson G, Bentzen SM, et al. Accelerated hyperfractionation (AHF) compared to conventional fractionation (CF) in the postoperative radiotherapy of locally advanced head and neck cancer: influence of proliferation. Br J Cancer. 2002;86(4):517-23.

26. Rosenthal DI, Mohamed ASR, Garden AS, Morrison WH, El-Naggar AK, Kamal M, et al. Final report of a prospective randomized trial to evaluate the dose-response relationship for postoperative radiation therapy and pathologic risk groups in patients with head and neck cancer. Int J Radiat Oncol Biol Phys. 2017;98(5):1002-11. 